\section{Commercial Insulin}

WE have received from Messrs. Burroughs, Wellcome and Co., London, a phial of "Wellcome" brand insulin prepared from crystalline insulin. This is the first commercial insulin to be made from the crystals and is available in 5 c.c. phials at 20 units per c.c. When insulin was first placed on the market some ten years ago, the potency of the material was only a fow units per milligram. For some time now, however, the potency of many commercial insulins has approximated that of the pure crystals, but this is the first time that the crystalline material has been employed for the preparation of insulin solution on the commercial scale. Crystals were first made by Abel in 1926 : the problem was further investigated by Harington and Scott in 1929, and more recently Scott has shown that the ease with which crystals can be obtained from amorphous insulin depends on the presence of small quantities of zine (or some other metals), and that all crystals prepared by the pyridine-brucine or saponin methods contain this element.

\section{Announcements}

LoRd D'Abernon, chairman since 1929 of the Medical Research Council, has been elected a fellow of the Royal Society under Rule 12, which provides that the Council may recommend for election in any calendar year not more than two persons who "have rendered conspicuous service to the cause of science, or are such that their election would be of signal benefit to the Society".

Mr. F. J. Marquis and Prof. W. W. Jameson have been appointed to fill vacancies in the membership of the Industrial Health Research Board of the Medical Research Council.

Dr. Kenneth Mellanby has been appointed Wandsworth scholar at the London School of Hygiene and Tropical Medicine. The purpose of the scholarship is research in tropical medicine, and the appointment is for a period of two years.

THE Director of the Geological Survey and Museum reports that Jermyn Street Museum is now vacated, and the library and collections have been transferred to the new Museum in Exhibition Road, South Kensington. The library is not yet in order, but the geological maps, British and foreign, are now available for consultation by the public. Admission may be obtained by the side entry in the courtyard between the Science Museum and the Geological Survey Museum.

THE next series of lectures and demonstrations on tropical hygiene at the London School of Hygiene and Tropical Medicine, which are intended for men and women outside the medical profession proceeding to the tropics, will be given by Lieut.-Col. G. E. F. Stammers and Sir Malcolm Watson on December 10-14 inclusive, 3.30-5 p.m. each day. The synopsis and other particulars can be obtained from the
Organising Secretary, Ross Institute of Tropical Hygiene, Keppel Street, Gower Street, W.C.1.

THE Secretaries of the Fourth International Congress for Applied Mechanics held in Cambridge last summer are about to go to press with the Proceedings of the Congress. So that the data contained may be at the disposal of all actively interested in the subject, the Organising Committee is prepared to issue copies at a price of $£ 1$ including postage (which sum does not actually cover the cost of printing and distribution). So that an adequate number of copies may be printed, those desirous of availing themselves of this offer are advised to make application forthwith to the Organising Secretary, Engineering Laboratory, Cambridge, England. The volume will contain the seven general lectures in extenso, abstracts of about 140 sectional papers and other data relating to the Congress.

Applications are invited for the following appointments, on or before the dates mentioned:-A research student (qualified medical practitioner) for six months at the Institute of Pathology and Research, St. Mary's Hospital, Paddington, London, W.2The Secretary (Nov. 12). A head of the Department of Continuative Education, Loughborough College-The Principal (Nov. 16). A lecturer in engineering at the Widnes Municipal Technical College-The Secretary, Education Office, Town Hall, Widnes (Nov. 16). A temporary junior assistant at the Experimental Station, Porton, near Salisbury-The Chief Superintendent, Chemical Defence Research Department, 14 Grosvenor Gardens, S.W.1 (Nov. 17). A lecturer (woman) in mathematics and science (biology) at the Training College for Women, Langham Tower, Sunderland-Chief Education Officer, Education Offices, 15 John Street, Sunderland (with stamped addressed envelope) (Nov. 19). An electric traction engineer to the New Zealand Government Railways-High Commissioner for New Zealand, 415 Strand, London, W.C.2 (Nov. 24). An explosives chemist for the Royal Gunpowder Factory, Waltham Abbey-The Principal Clerk, Central Office, Royal Gunpowder and Small Arms Factories, Enfield Lock, Middlesex (Nov. 24). An assistant to the Secretary of the Institution of Naval Architects-The Council of the Institution, 2 Adam Street, Adelphi, W.C.2 (Dec. 1). An assistant lecturer in mechanical engineering at the Manchester Municipal College of Technology-The Principal (Nov. 26). A University demonstrator in pathology at the University of Cambridge_-Prof. Dean, Department of Pathology, (Dec. 1). Librarian at the British Postgraduate Medical School (University of London)-The Dean, British Postgraduate Medical School, New Public Offices, Whitehall, S.W.1. A professor of modern experimental physies at the National Central University, Nanking, and a professor of hydraulic engineering at the National Chekiang University, Hangchow, China--Universities China Committee in London, 91 Gower Street, London, W.C. A research fellow (experience in gas analysis) at the Liverpool Heart Hospital-The Secretary, Miss Lewis, 14, Cook Street, Liverpool. 